\title{
Review \\ Post COVID-19 Pandemic Scenarios in an Unequal World Challenges for Sustainable Development in Latin America
}

\author{
Juan Pablo Morea 1,2
}

check for

updates

Citation: Morea, J.P. Post COVID-19 Pandemic Scenarios in an Unequal World Challenges for Sustainable Development in Latin America. World 2021, 2, 1-14. https://dx.doi.org/ $10.3390 /$ world 2010001

Received: 20 November 2020 Accepted: 21 December 2020 Published: 24 December 2020

Publisher's Note: MDPI stays neutral with regard to jurisdictional claims in published maps and institutional affiliations.

Copyright: () 2020 by the author. Licensee MDPI, Basel, Switzerland. This article is an open access article distributed under the terms and conditions of the Creative Commons Attribution (CC BY) license (https: / / creativecommons.org/ licenses/by/4.0/).
1 Consejo Nacional de Investigaciones Científicas y Técnicas (CONICET), Mar del Plata 7600, Argentina; juanpablomorea@gmail.com

2 Centro de Investigaciones Geográficas Socioambientales, UNMDP, Mar del Plata 7600, Argentina

\begin{abstract}
The COVID-19 pandemic has prompted numerous academic debates about its impact on health and the economy and on possible post-pandemic scenarios across the globe. The discussion has been focused on whether the pandemic will mark a turning point and a unique opportunity to generate radical changes in the economic and productive system, or if the State assistance role will, once again, serve to rescue the capitalist system. There is a common link between these two opposing positions in that there will be a crossroads for the future of humanity, regarding the treatment that will be given to nature. However, some of the most optimistic visions seem to underestimate the different realities that the world presents. This paper proposes a combined analysis about the possible post-pandemic scenarios that are debated at a global level, and the impacts of the pandemic in the context of Latin America to fill an information gap and to aid understanding on what the possible post-pandemic scenarios for Latin America could be. The first findings show that the debates about the post-pandemic future at the global level could be grouped between: the return to "business as usual"; a managed transition; and a paradigm shift. For Latin America, the post-pandemic scenario will be highly conditioned on how the new world order is reconfigured, and moving on a path towards sustainability for the region in the post-pandemic scenario seems to be linked to two possibilities: a kind of revolt or revolution fostered by the social bases; or a solution of a global nature that favors making long-term decisions. If this does not occur, the most likely scenario seems to be a return to business as usual.
\end{abstract}

Keywords: COVID-19; post pandemic; sustainable development; Latin America

The post-pandemic scenario will be highly conditioned on how the new world order is reconfigured. At the political level, it is most likely that the countries will follow the trend that is consolidated at the global level and the possibilities of establishing significant changes are tied to global solutions.

The most likely scenario seems to be a return to business as usual, but there are movements and situations on a global and local scale that could lead to a change in trend.

\section{Introduction}

The COVID-19 pandemic, several months after its beginning, has not only had great consequences for health, but has also brought to light the criticism of capitalism and of an economic system that definitively threatens the scope of the sustainable development. Therefore, numerous academic analysis has arisen regarding the multiple impacts that the pandemic is generating and on possible post-pandemic scenarios across the globe.

We are still dealing with the health consequences of COVID-19. It is true that the studies that present results referring to the impacts on health and the search for the vaccine attract the most attention. However, the debates about the future of humanity have already begun. Special issues dedicated to COVID-19 have proliferated in the world's most important scientific journals. As Bringel [1] has summarized, in the first months an antagonism was observed between optimistic and pessimistic discourses. 
Optimistic views suggest that this is an opportunity to promote sustainable societies and economies, and interpret the events as a call for change [2]. The most negative views estimate that once the pandemic is over, the rules of the game will not change dramatically, beyond some strictly necessary adaptations [3].

It is noteworthy that an important part of the first discourses analyzing the postpandemic situation-especially in the literature in English and coming from the central countries - encouraged an optimistic future based on a change in the world system and the end of capitalism. However, these discourses can be naive or unrealistic if they do not contemplate the different realities that the world presents. The truth is that fostering more sustainable societies, or "taking the opportunity" to make radical changes in the economic system may be more feasible for some countries than for others [4].

It should not be ignored that we live in a very unequal world. Those countries that belong to the group of the most important economies in the world, or are smaller economies but belong to the so-called developed countries, will be better positioned to face the challenges of the future. These groups of countries not only have greater resources and possibilities, they also better meet the socioeconomic needs of their populations. These factors will surely provide a better starting point to face the post pandemic.

Alas, these are not the only differences that must be considered. In recent years, several international agreements related to climate change and sustainable development have been promoted. The degree of compliance of these international agreements is also very uneven and those countries that have shown greater commitment have better possibilities of fostering more harmonious relations between societies and nature.

Another important issue associated with the pursuit of sustainable development is the level of dependence of some countries on certain unsustainable economic practices. In general, those less developed countries have economic models highly dependent on extractive activities, the primary economy, and the exploitation of natural resources.

The last big thing to consider is related to wars or socio-political conflicts. In countries that are in these situations, the pandemic has impacted in a very different way. Consequently, the post-pandemic scenario will present different challenges and priorities. Hence, it is necessary to question if we can talk of a global post-pandemic scenario. The central issue is whether all countries are in a position to face the transformations that a radical change in the economic system would imply?

So far, although the international community has mobilized to understand how the pandemic is affecting our societies and the environment, a holistic analysis of how the pandemic is affecting different parts of the world is missing, especially those countries and regions that have fewer resources and possibilities to carry out the necessary investigations. Hence, future research should gather data to better understand the impacts of the pandemic locally and globally.

To help to fill this gap, this work analyzes the case of one of the least favored regions of the world: Latin America. The main objective is to establish a comparison between global trends and which will be the most likely post-pandemic scenarios in the medium term for the region. This analysis will be mainly aimed at evaluating whether the region will be in a position to favor a shift towards sustainability as predicted by the most optimistic views.

The paper starts with an analysis about the possible post-pandemic scenarios that are debated at a global level, whilst understanding the different starting points that Latin America will have. To achieve this, relevant information is presented about the impacts and consequences of the pandemic in the region. The proposed approach assesses the impacts of the pandemic without neglecting structural problems, the socioeconomic situation and the characteristics of the prevailing economic model. From that information, it will be possible to provide a vision of the post-pandemic scenario adapted to the context of the region and to analyze how the redefinition of the world order will affect the realities of Latin American countries. It will also be possible to suggest what might be the most possible future scenarios, what would be the global necessary conditions to start a path 
towards sustainability, and to identify some determining factors of the possibilities of Latin America to promote sustainability models.

\section{Materials and Methods}

The article presents a non-structured review where documentary research and bibliographic reviews were essential methodological strategies. In accordance with the objectives, the material collection was carried out through Google Scholar, ScienceDirect and the web pages of different scientific journals looking for articles related to COVID-19 in the areas of environmental sciences, multidisciplinary journals, political science, geography and planning, sociology and international relations. The search was supplemented with documents and reports from international organizations, regional, national and subnational agencies. Papers and documents were selected by searching the titles, abstracts, and keywords for the terms "post pandemic scenarios"; "post pandemic future"; "post pandemic transformations"; "post COVID-19"; "COVID-19 + impacts"; "COVID-19 + opportunities" "COVID-19 + sustainability"; "COVID-19 + economic crisis"; "COVID-19 + Sustainable Development Goals"; "COVID-19 + environment"; “COVID-19 + Latin America”.

The process comprises three stages: analysis of the debates about possible postpandemic scenarios at the global level, analysis of the impacts of the pandemic in the context of Latin America, and analysis of possible future scenarios and challenges for sustainable development in Latin America.

For the first stage, literature in English and Spanish were selected, prioritizing those works that addressed the impacts on the environment, sustainable development, geopolitics and the post-pandemic. At this stage, documents from international organizations such as the United Nations (UN), the International Labor Organization (ILO) or the World Bank were also predominant.

Subsequently, an analysis was carried out on those articles assessed as most relevant, identifying the different perspectives and classifying the views of the different authors between positive, negative and uncertainty.

For the second stage, literature in Spanish was prioritized, or in English but from Latin American authors. Also deemed important were the reports from the regional divisions of international organizations such as the Economic Commission for Latin America and the Caribbean (ECLAC), OIL, or the Latin America and the Caribbean of the United Nations Development Program (UNDP), or reports from national agencies and NGOs.

In the first place, the analyses carried out were aimed at estimating the impacts of the pandemic in the region at a socio-economic and socio-environmental level. Subsequently, this information was contrasted with evaluations and reports about the environmental crisis, the search for sustainable development and the social and economic problems of the region.

The results of the previous stages are the basis for the third stage of the approach. The interrelated analysis between the possible post-pandemic scenarios, the impacts of the pandemic and the characteristics and intrinsic problems of the region made it possible to assess what the most likely future scenarios for the region could be. This analysis also made it possible to establish the main challenges to advance towards sustainable development.

\section{Literature Review}

\subsection{Post-Pandemic Scenarios as an Opportunity for Sustainable Development at the Global Level}

The post-pandemic scenario is uncertain. The impacts of this pandemic are difficult to estimate in the medium and long term and this gives rise to much speculation about the future. In addition to monitoring the number of infections and deaths worldwide, there were some situations that were observed in a generalized way and that prompted the first discussions regarding the future scenario: the lockdown situation and the almost absolute braking of the economic and productive system, the central and protagonist role assumed by the nation states to alleviate the effects of the pandemic and provide assistance at the 
socio-economic level, and the critics of capitalism and the relationship between societies and nature.

The central axis of the criticism of the current economic system was centered on the forms of use and exploitation of nature and the resulting consequences. Although the origins of COVID-19 have also been discussed, the spread of this virus has alerted us to the health risks that certain types of animal-based food productions have. The coronavirus outbreak served to highlight, once again, the link between the loss of habitats and biodiversity and the increasing likelihood that infections will spread from wildlife to humans as zoonotic diseases [5].

It is true that there are numerous previous antecedents of these types of consequences, but the magnitude of COVID-19 has generated a feeling that humanity has reached a turning point. There is a common link between different positions that there will be a crossroads for the future of humanity regarding the treatment that will be given to nature.

This idea was reflected by Hodges and Jackson in an editorial of the journal Science: "we have a once-in-a-generation opportunity to rethink how we grow back our economies in a way that does not imperil the global environment as we have in recent decades" [6] (p.1). In line with that vision, Springer considered that capitalism is a system that destroys the planet and expressed that COVID-19 "serves as a testament to the fact that the selfishness of capitalism was never going to produce a world in which we could find comfort" [7] (p. 112).

From these positions, an idea began to grow that COVID-19 presents opportunities for a positive change. Some voices considered that learning from this experience should lead us towards a new world economy with strategies to safeguard both biodiversity and human well-being [2,8]. The main argument for believing in this change relies on the fact that the magnitude of the crisis will inevitably lead to the downsizing of the consumer economy and fundamental changes in the global production networks and supply chains $[9,10]$. From this perspective, national governments and intergovernmental organizations should adopt clear strategies to promote the necessary changes [2,6,11].

Other voices say that the possibilities of believing in a change depend not upon the state, capitalism, and not upon any authority, but in the positive social reactions and an outpouring of mutual aid and social solidarity to assist those in immediate need [7,12]. Mutual aid, care and cooperation can be the base to reconfigure society based on an integration of people and nature $[7,12,13]$

On the other hand, the most pessimistic views believe that after the pandemic there will be no major changes. As Harvey [14] expresses, for example, the economic crisis will cause employment to fall to levels like those of the 1930 crisis. According to the World Bank, up to 100 million people could fall into extreme poverty in 2020 [15]. According to some recent records of the ILO, about 585 million full-time jobs have been lost in the first half of the year worldwide and for the second half, a loss of up to 590 million full-time jobs is estimated [16].

This will force the nation states to promote a rescue like that of the 2008 crisis, but this time, in favor of mass consumerism to rescue the current capitalist system [14]. It is precisely this leading role in the assistance of the economic and productive sector that the states assumed that leads us to believe that after the pandemic "business as usual" will continue $[1,3,14,17,18]$.

From these two opposite visions, the discussion was focused on whether the pandemic will mark a turning point and a unique opportunity to generate radical changes in the economic and productive system, or if the state assistance role will, once again, serve to rescue the capitalist system.

The search for sustainable development is not something new. The truth is that for nearly 30 years sustainability scientists and policy makers have pursued this objective [11]. What needs to be addressed are the true possibilities of carrying out sustainability transformations from the aftermath of COVID-19. As Cohen points out, COVID-19 has reinforced the discussion and "is simultaneously a public health emergency and a real-time experiment in downsizing the consumer economy" [11] (p. 1). 
The biggest question for the future is if COVID-19 can provide a window of opportunity for promoting sustainability transitions. In favor of the most optimistic views, COVID-19 has debunked the myth that current forms of production and consumption are the only options. To take this window of opportunity it is necessary "to reflect upon which aspects of the 'old normal' should be retained and where it is time to create a more sustainable 'new normal'" [19] (p. 63). This will require planning, increase current and future willingness to do the necessary behavioral changes, and a clear strategic of communication [15].

The first interrelated analyses between the pandemic and its effects on sustainability highlighted that the decrease in economic activity and human mobility is favoring interesting ecological reactions, as a kind of resurgence of nature $[13,20]$. Some initial studies have been able to register positive effects such as reducing emissions in China and in the world's big cities [14,21], a drastic decrease in air and water pollution levels [6] and some changes in the behavior of animals and other benefits for environments and species have been visible due to the reduction of human pressure [22].

Nevertheless, we must avoid falling into simplistic or naive speeches regarding the environmental crisis. Assuming that nature has an inherent capacity to heal itself downplays the need for urgent environmental action [23]. It should not be ignored that the first positive ecological reactions are only temporary and that a constant level of slowdown in the economy should be maintained for a long time to consolidate the benefits. In fact, there is a negative side of the pandemic for the conservation of biodiversity related to the lack of funds, personnel and structure to carry out tasks on protected areas and other important natural spaces $[22,24,25]$.

Therefore, thinking about whether the post-pandemic scenario can be favorable for rebuilding our societies towards sustainable development requires more in-depth evaluations regarding certain sustainability indicators. In this sense, to have a global vision, the 17 Sustainable Development Goals (SDGs) of the UN are an unavoidable reference.

According to the last 2020 UN Sustainable Development Goals report, even before the pandemic, most goals and targets were not going to be reached by 2030 [26]. COVID-19 has worsened the global situation and has produced devastating impacts [20]. However, the same report acknowledges that only the initial impact of COVID-19 on specific goals and targets can be measured due to difficulties in conducting surveys and statistics.

From this situation, Nerini et al. [17] have investigated how the COVID-19 crisis impacts the 169 targets of the SDGs. The results of this study show that "the pandemic negatively affects the achievement of 144 targets (almost 90\%) of the SDGs. However, 66 targets (ca. $40 \%$ ) could potentially benefit from the changes spurred by the crisis, given that the appropriate decisions are made" [13] (p. 2).

Regarding the negative effects, COVID-19 has severe cascading impacts that affects SDGs related to health, wellbeing, poverty, education, vulnerable and marginalized groups, employment, economic growth, equity, justice, and some issues related to environmental targets [13]. In the case of targets that could potentially benefit from the current situation, the results of this study agree that reduction of economic activity and mobility can positively affect SDGs related to pollution, emissions, ecosystem restoration and present and opportunity "to rethink sustainability and resilience of food, water and energy supply chains (SDG 2, 6 and 7)" [13] (p. 5). However, these opportunities depend on short and medium-term decisions that may potentially push actions to consolidates the benefits. What is clear is that the post-pandemic scenario is open, and depending on decisions at a global and local level, the world could either take the opportunities presented by the crisis or get further away from achieving the SDGs $[11,17-19,27]$.

\section{Debates on the Post-Pandemic Scenario at the Global Level}

The analyses carried out in the previous section show a strong dichotomy between optimistic and pessimistic discourses. However, when analyzing the debates about the post-pandemic future, the different proposals could be grouped and synthesized between 
three great horizons: the return to "business as usual", a managed transition, and a paradigm shift.

The return to "business as usual" is aligned with less optimistic views that consider that the size of the economic crisis will drive, with some minor adjustments, the search for market recovery and rapid economic growth [14,18,28-30]. The strongest argument of these views considers that as the pandemic spreads and the economic crisis advances, countries will favor solutions that prioritize short-term economic gain. It is also true that the economy has been hit hard, and to promote a rapid recovery, it is logical to resort to the classic and familiar instruments. The blind spot is the evolution of social reactions and changes in pursuit of sustainable development, but if civil society is weaker in the post-COVID-19 period, this scenario will be more likely [18].

Taking advantage of the opportunities generated by the pandemic to advance towards sustainable development will require that the critical voices and social demands that have arisen be consolidated in the post-pandemic period. If this happens, two types of scenarios could emerge: a paradigm shift associated with a chaotic situation, or the start of a planned transition.

In the first case, the COVID-19 outbreak could be the global catastrophic event that generates the collapse of the global economic order. This would mean putting the environmental and climate crisis at the center and making the necessary changes to promote true sustainability transformations [31]. A paradigm shift, thus understood is based on a total rethinking of natural resource management, animal-based food production, supply chains, and the relationship of societies with the environment in general [10]. The most radical views understand that we need a permanent shift to a sustainable society based on a new version of glocalization, otherwise, we will not have long left on this planet as a species [32]. In favor of these discourses are the first positive ecological reactions and the concern of civil society. The fear of repeating an experience such as the coronavirus could lead to the drastic measures that we have not been able to adopt so far. However, this scenario seems the most difficult to carry out, not only because of the magnitude of the necessary change but also because of the record of many adverse effects that the pandemic has had in the search for sustainable development.

However, the coronavirus pandemic could also generate a planned transition, a managed transition or a managed degrowth [1,18]. In this case, COVID-19 could act as a starting point to change some behaviors relative to the business-as-usual system. This intermediate position is those with the greatest presence in the analyzed literature and is based on the consolidation of a "Green New Deal" [18,33-35] centered on sustainable consumption, reduction of the economy in scale, promotion of the circular material economy [9,11,19,30,32,36,37] and supported by the "Green Economy" and "Blue Economy" [38-41]. Considering the profound implications of a paradigm shift, thinking about a gradual process of change seems more likely in the short and medium term.

However, at least two major questions arise in this possible scenario: how would this potential transition process take place? How would it manifest itself in the different regions of the world? The issues associated with the first question is whether this transition process would lead to a change that really solves the problems of the present. This is probably the weakest point of this type of proposal.

The second question is related to how the new geopolitical map and the power relations between the different countries and regions will be shaped. This could be a strong determinant of the real possibilities of promoting a change in the system that spreads globally.

Therefore, think about a post-pandemic scenario at the global level. It would also imply making certain considerations regarding the geopolitical scenario and the reconfiguration of the world order. If the scheme of centralities and peripheries and the assignment of roles for the functioning of the capitalist system remains, this does not seem viable.

To imagine the post-pandemic period, it is necessary to consider the differences that may arise in different regions of the world. The pandemic will impact more crudely in the 
less favored regions not only economically, but also from their socio-political stability [4,42]. Undoubtedly, the starting point will be different. If we think about the importance that society's relationship with nature is going to have, it is questionable how those regions so dependent on the exploitation of their natural resources will be able to face the challenges. For all these reasons, the case of Latin America requires special attention.

\subsection{Impacts of COVID-19 in Latin America}

The impacts on health of COVID-19 in Latin America have been closely related to what happened in other regions of the world. The reactions of the nation states also followed a global trend: more or less strict quarantines, social distancing measures, reduction of economic and social activity; and intervention and support measures to mitigate the economic effects.

The lockdown had a significant impact on the economy and the region-like the rest of the world-will have to propose strategies for economic recovery. According to the regional director for UNDP, it is estimated that more than 30 million people may fall into poverty [43]. The ECLAC forecasts an average drop of $9.1 \%$ in gross product for the countries of the region and a $25 \%$ drop in the price of raw materials, something that will undoubtedly strongly affect economies of all countries [44].

The effects of the pandemic have been catastrophic for the region. Economies and labor markets have suffered the largest contraction in the last 100 years with a total loss of about 85 million jobs (47 million in the second quarter alone) [16,45]. This means that recovery will be slow and it will take several years to regain pre-pandemic levels. It will also mean that states will have to make great efforts to incentivize investment and promote employment [31].

From an ecological point of view, Latin America is experiencing both positive and negative effects. As has happened in other parts of the world, the lockdown has led to a decrease in emissions, pollution and an improvement in air quality. This effect has been visible in all the capitals and large cities of the region. However, with the progressive economic reactivation these positive effects began to diminish [46].

On the other hand, some environmental problems have worsened. The COVID-19 lockdown was an opportunity for those behind the illegal fires. The first documents produced by the UNDP show that deforestation processes are increasing in many countries due to the redirection of funds and resources [46].

A report by Open Democracy [47] revealed a 64\% increase in deforestation in the Brazilian Amazon in April and a 200\% increase in forest fires in the region. The National Institute for Space Research (Inpe) recorded 17,326 fires in the Brazilian Amazon, compared to 7855 in October 2019, an increase of 121\% [48]. In the Colombian Amazon, there was an increase in fire sources of $276 \%$, representing a loss of 75 thousand hectares. In addition, the authorities have denounced that armed groups have forced officials from the Natural Parks of Colombia to abandon 10 parks in the Amazon area [49].

The case of Argentina has also been striking, where by August 2020 there were an estimated 175 thousand hectares of forests and wetlands under fire. Beyond some climatic factors such as droughts, rising temperatures and strong winds, environmental organizations and the Nation's Minister of the Environment himself denounced the intentionality of most of the fire sources [50].

Regarding the possibilities of advancing towards sustainable development, the impacts of COVID-19 in the medium term reinforce a trend of delay in the region in the sustainability agenda. The Center for Sustainable Development Goals for Latin America and the Caribbean recently presented the indices of the first performance evaluation for the period 2015-2019 and progress is below expectations [51]. Only Chile, Uruguay and Trinidad and Tobago have been able to achieve the fulfillment of any of the objectives, but in general terms, there are very significant delays.

The same center presented a first analysis of the possible impacts of the pandemic on the scope of the SDGs for the region. Although it is too early to reach definitive conclusions, 
what emerges from the analysis is that, in the short term, COVID-19 will have a negative effect. When making projections on the evolution of each objective, a decline is expected in 61 of the 96 indicators considered [52].

Although these data reflect that Latin America follows a global trend, the impacts and consequences of COVID-19 appear to be more profound. Projections warn that the region will experience a crisis unprecedented in its modern history. This will generate important environmental impacts associated with cuts in the environmental area and the difficulty of complying with legal frameworks for environmental protection due to economic losses [53].

The truth is that this coronavirus has deepened a historical territorial and environmental problem in the region that is largely explained by a deregulated advance of the productive system and the primacy of the interests of capital over the needs of environmental systems [54-58]. A book recently published by ECLAC warns that Latin America is on the brink of an environmental tragedy caused by the adoption of an economic model based on the opening of regional economies that consolidated the role of all countries as suppliers of raw materials for globalized value chains [59].

At the beginning of this century, the Chinese leadership led to the boom of commodities in a new geopolitical order based on environmental relations with a very clear subordinate role for Latin America [60-62]. The high prices that the raw material acquired in the world market intensified certain practices and deepened the existing matrix. In addition, the deepening of this model has been accompanied by using violence, an increase in inequality, processes of exile and dispossession and socio-environmental conflicts of the most diverse nature.

These problems, along with the questions about the true possibilities of generating a reduction in poverty and better living conditions from this type of development model, have been arduously discussed in Latin America under the meanings of extractivism or neo-extractivism [60,62-67].

The questions to the extractivist model and the resulting environmental crisis are fundamental, considering the challenges posed for the post-pandemic period. It is necessary to ask how Latin America could meet the forecasts of the optimistic visions that encourage a radical change of model, especially because of the difficulty of combining the prevailing models with the commitments signed by Latin American countries in the search for sustainable development.

\section{Discussion of Post Pandemic Scenarios in the Context of Latin America}

Based on the analysis of the previous section, it becomes necessary to ask which of the possible scenarios that are predicted globally will be the most likely for the Latin American context. Although it is too early to venture certain future scenarios, there is a chance that the coronavirus pandemic will put nature at the forefront of the global geopolitical discussion [68].

This means that. for the context of Latin America, the questions will be raised again around the management of natural resources. Hence, the possibility of promoting a paradigm shift for the region would imply abandoning the extractivist model or generating a significant restructuring. Another factor that undermines the possibilities of generating a radical change is the role of nation states. We have seen how, from COVID-19, states have gained prominence around the world and it is expected that the recovery after the pandemic will take place hand in hand with a strong role and state interventionism. The problem with the latest wave of the extractive boom in Latin America is that governments have been facilitators and promoters of the extractivist model that have had a high environmental impact, and that today are at the center of criticism of the sustainable development discourse [58,64,69-72]. Thinking about recovery, the main question will undoubtedly be placed on how states can be drivers of sustainability transformations when they are so involved in a model that has given ample evidence of heading in the opposite direction.

Some movements are already beginning to be observed and do not exactly support the theory of the change of model by the political spheres. There has been no decrease in 
livestock farms and a large part of the registered fire outbreaks respond to the intention of expanding productive frontiers.

A witness case may be that of Argentina, which at the peak of the pandemic was about to close an agreement with China to double the intensive production of pigs with an investment of $\$ 3.5$ billion dollars for the next four years. The rejection of civil society due to the high environmental impact and the potential focus of future pandemics of the project prompted some modifications in response to environmental issues. However, social pressure was not enough to stop the project [73].

Analyzed data on the economic impact of the pandemic agree that the region faces an unprecedented crisis in modern history. For many Latin American countries, short-term emergencies will promote a trend continuity of the current model. These data encourage the voices of those who consider that business as usual is the most likely scenario.

How the new world order is reconfigured and the role of China will be central to the future of Latin America. The aforementioned example from Argentina shows that as long as extractive activities present high returns, this model will continue to be used. If the relationship between central and peripheral countries is not reconfigured in terms of greater equality and solidarity, it is unlikely that less favored regions such as Latin America will be able to establish a system change [74].

In Svampa's vision of a post-coronavirus world:

"The solution is global and requires a radical reformulation of North-South relations, within the framework of democratic multilateralism, which aims at the creation of national states in which the social, the environmental and the economic are interconnected and at the center of the agenda" [33] (p. 1).

If this is not the case, it is difficult for Latin American states to abandon a matrix so dependent on the exploitation of natural resources. Furthermore, if there is no mechanism for economic solidarity, the countries of the region will not have the necessary resources to face a change in the economic model. According to the views of the post-pandemic at the global level, the future scenario that gathers the most consensus is that of a managed transition. For Latin America, the existence of this type of mechanism is also necessary to initiate a transition.

In this sense, the pandemic has given rise to certain signals that previously seemed unthinkable or were part of philosophical debates that touched the plane of utopia. The World Bank has already made 160 billion dollars available for low-income countries for the pandemic response [75] and the UN has called for a 2.5 trillion coronavirus package for developing countries [76].

On the other hand, different sectors are seriously promoting the possibility of establishing a universal income [33]. Although this proposal is not new, the blows of the pandemic have put it at the forefront like never before. In fact, the United Nations Development Program proposed to apply this income temporarily to some 2700 million inhabitants around the world [77], and countries such as Germany have begun the first tests to study its effects on the behavioral practices of the population and establish its viability [78]. This type of initiative would allow many Latin American countries to meet the basic needs of the population and resolve the most urgent demands to concentrate their efforts on building development models supported by sustainability transformations. Similar situations will be necessary in other disadvantaged regions of the world. The post-pandemic recovery will present similar difficulties in most of Africa, in India, or in countries undergoing war situations or great conflict in the Middle East such as Palestine, Lebanon, Syria, among others [79-81].

Due to the recognized magnitude of the economic crisis and the socioeconomic structural problems, the consolidation of this type of mechanism is essential to initiate a managed transition.

If that is not the case, generating a fundamental change would imply a kind of social revolt that forces the political power to change course. Until recently, thinking about social 
revolutions or profound transformations seemed unlikely. However, a variety of events unleashed during 2019 and 2020 suggests that it would not be something so far-fetched.

The events that occurred in Chile, Ecuador and Bolivia during the past year have lit alarm lights for the entire political and economic system of Latin America. Claims against increases in fuel (Ecuador) or in the price of public transport rates (Chile) are frequent in most countries. What is not so common is that protests of this type acquire the level of convocation, the prolongation for months and the degree of violence that they had in these cases.

It is interesting to note that the reasons that triggered the conflicts were linked to problems common to most of countries. This is the main reason that indicates that there is generalized fragility and that similar situations could occur in the rest of the region. In relation to the challenge of promoting sustainability transformations, these facts are proof of the difficulties that the region has had to promote inclusive development models that are representative of the needs of society $[14,58]$. They are also proof of nonconformity and a situation of exhaustion with governments and the political system, beyond the specific reasons for the protests.

In fact, the protests that began in Chile in 2019 ended up favoring a referendum for a new Constitution in October 2020. The referendum was approved and a process began to repeal the Chilean Political Constitution approved in 1980 during the dictatorship of Augusto Pinochet.

Social and political instability in the region continues. As this article is being written, a political crisis is unfolding in Peru. On 9 November 2020, the Peruvian Congress approved a motion to remove President Martín Vizcarra, an action denounced as a "coup" by the government. The arrival of Manuel Merino to the Presidency was received with strong protests in several cities of the country, not in support of the dismissed Vizcarra, but against the maneuvers of Congress. Merino had to resign because of the death of several protesters and Francisco Sagasti took office, becoming the third president in 8 days $[82,83]$.

These are examples of the renewed momentum that social protests have acquired in Latin America. The possibility of promoting a paradigm shift may be associated with this type of background, in view of the pressure that has been exerted to mobilize structural changes.

Certainly, the post-pandemic outlook for Latin America will have some differential characteristics from global trends. The circumstances behind the three scenarios that are debated globally are different. The constant economic crises, the high dependence on the extractivist model and the socio-political conflicts are conditioning factors. The most likely scenario seems to be a return to "business as usual", but there are movements and situations on a global and local scale that could lead to a change in trend.

\section{Final Considerations}

The post-COVID-19 pandemic will be a new conditioning factor for short and mediumterm global policies that will affect the search for sustainable development. The magnitude of this pandemic will undoubtedly produce a global geopolitical reordering that will force us to rethink the economic, political and socio-environmental system. The question that will remain latent is whether the post-pandemic scenario will present itself as a true and almost unique opportunity (at least for this generation) to promote the changes and transformations that until now we have not been able to face, or, on the contrary, it will be a new crisis in which the nation states will come out to rescue the capitalist system.

If there is a positive turn, the other question that must be resolved is how to achieve a change that spreads globally in such an unequal world. In principle, the data analyzed and the results presented seem to indicate that the starting point and future possibilities will not be the same for all countries.

The main findings of this study show that the post-pandemic scenario will not be the same in all regions of the world. Specifically, for the case addressed, it is shown that once the pandemic has been overcome, Latin America will find itself in a very disadvantaged 
situation to face the challenges of the future. In Latin America, economy and health have been as impacted as in the rest of the world. However, it is possible to recognize at least four factors that will make post-pandemic recovery even more difficult: the economic fragility of states to provide assistance, the environmental problems that have accelerated in this period, the delay in meeting the SDGs, and the excessive dependence on a model based on the exploitation of the environment and natural resources.

The post-pandemic will not be the same, in addition to these four factors, because Latin America has a series of structural problems that need to be solved. The region continues to be the most unequal in the world and one of the most violent and dangerous. It has high poverty rates and fewer resources due to constant economic crises, high levels of indebtedness and the historical difficulty of consolidating development models.

For this reason, the speeches that promote a post-pandemic scenario as a unique opportunity to generate a change in the system or to initiate a transition process through proposals such as the green new deal should not ignore that if the solution depends only on the capacities of the countries in the region, the possibilities of promoting profound transformations diminish. Above all, due to the difficulty of facing the challenge of how to reconcile the need for urgent responses when transformation processes require longterm decisions.

According to the analyses developed, the first political signs and movements of the economic system seem to indicate a commitment to the continuity of the model. With so many people suffering unemployment and with so many needs to cover, the short-term benefits of "business as usual" will be compelling. For this reason, moving on a path towards sustainability for the region in the post-pandemic scenario seems to be linked to two possibilities: a kind of revolt or revolution fostered by the social bases, or to a global solution that favors long-term decision making.

The first alternative does not seem so far away today due to the recent antecedents and the strength that environmental movements have gained in the face of the pandemic. This reinforces the view expressed by Springer that the hope for change does not lie with governments or institutions but with civil society.

The other possibility is related to the visions that bet on global solutions where the effects of the pandemic re-signify the relations of the countries in terms of greater equality and fraternity. To achieve global change, the relations between central and peripheral countries must be reformulated based on the recognition of the limitations of the least favored to face radical changes.

The future of humanity after the pandemic is uncertain and it is too early to establish strong definitions. Latin America starts from a disadvantageous situation in terms of the possibilities of fostering true transformation processes. The post-pandemic scenario will be highly conditioned on how the new world order is reconfigured. At the political level, it is most likely that the countries will follow the trend that is consolidated at the global level and the possibilities of establishing significant changes are tied to global solutions.

The exception to this rule could come from the evolution of the social climate of the region. The year 2019 may have marked a turning point, and it will be necessary to observe how social movements will react after the pandemic. The force of the claims in Chile succeeded in repealing a constitution elaborated under the Pinochet dictatorship. Claims for illegal fires have been massive in all countries and global youth environmental movements are organizing in the region as well.

It should not be ignored that they are incipient processes and it is impossible to foresee their evolution with certainty. However, the results achieved so far are auspicious and depending on the strength of the claims and the social pressure they can exert, some structural changes could be favored. In any case, the role of the States will be very important, but not only because of the need to accompany the economic recovery, but also because of the urgency of solving historical structural problems. Imagining a postpandemic future in Latin America aligned with positive views will necessarily depend 
on giving favorable responses to social demands, of reducing inequality, and addressing environmental problems.

Funding: This research received no external funding.

Institutional Review Board Statement: Not applicable.

Informed Consent Statement: Not applicable.

Data Availability Statement: No new data were created or analyzed in this study. Data sharing is not applicable to this article.

Conflicts of Interest: The author declares no conflict of interest.

\section{References}

1. Bringel, B. Geopolítica de la pandemia, escalas de la crisis y escenarios en disputa. Geopolítica 2020, 11, 173. [CrossRef]

2. Pearson, R.M.; Sievers, M.; McClure, E.C.; Turschwell, M.P.; Connolly, R.M. COVID-19 recovery can benefit biodiversity. Science 2020, 368, 838-839. [PubMed]

3. López, F.J.S. Espacialidad y pandemia: La crisis del coronavirus vista desde la geopolítica negativa. Geopolitica 2020, 11, 69. [CrossRef]

4. Sumner, A.; Ortiz-Juarez, E.; Hoy, C. Precarity and the Pandemic: COVID-19 and Poverty Incidence, Intensity, and Severity in Developing Countries. In WIDER Working Paper, 77th ed.; Helsinki: Helsinki, Finland, 2020; Volume 2020, ISBN 978-92-9256-834-4.

5. Hodges, K.; Jackson, J. Pandemics and the global environment. Sci. Adv. 2020, 1-2. [CrossRef]

6. Springer, S. Caring geographies: The COVID-19 interregnum and a return to mutual aid. Dialogues Hum. Geogr. 2020, 10, 112-115. [CrossRef]

7. Cohen, M.J. Does the COVID-19 outbreak mark the onset of a sustainable consumption transition? Sustain. Sci. Pr. Policy 2020, 16, 1-3. [CrossRef]

8. Bennett, J. Reorienting the post-coronavirus economy for ecological sustainability. J. Aust. Polit. Econ. 2020, 85, 212-218.

9. Sarkis, J.; Cohen, M.J.; Dewick, P.; Schröder, P. A brave new world: Lessons from the COVID-19 pandemic for transitioning to sustainable supply and production. Resour. Conserv. Recycl. 2020, 159, 104894. [CrossRef] [PubMed]

10. Strauss, S. Some Emerging Hypotheses on the Economic Opportunities and Challenges of the Post-Pandemic World; Social Science Research Network: Rochester, NY, USA, 2020.

11. Cohen, M.J. Does the COVID-19 Outbreak Mark the Onset of a Sustainable Consumption Transition? Taylor \& Francis: Washington, DC, USA, 2020; ISBN 1548-7733.

12. Tolentino, J. What Mutual Aid Can Do During a Pandemic. Available online: https://www.newyorker.com/magazine/2020/05/ 18/what-mutual-aid-can-do-during-a-pandemic (accessed on 14 September 2020).

13. Rose-Redwood, R.; Kitchin, R.; Apostolopoulou, E.; Rickards, L.; Blackman, T.; Crampton, J.; Rossi, U.; Buckley, M. Geographies of the COVID-19 pandemic. Dialogues Hum. Geogr. 2020, 10, 97-106. [CrossRef]

14. Harvey, D. Política anticapitalista em tempos de COVID-19. Sin Permiso 2020, 22, 1-11.

15. World Bank. Global Economic Prospects. Available online: https://www.worldbank.org/en/publication/global-economicprospects (accessed on 19 November 2020).

16. OIT. Observatorio de la OIT: La COVID-19 y el Mundo del Trabajo, 5th ed.; OIT: Geneva, Switzerland, 2020; Volume 26.

17. Nerini, F.F.; Henrysson, M.; Swain, A.; Swain, R.B. Sustainable Development in the Wake of COVID-19. Res. Sq. 2020, 1-15. [CrossRef]

18. Wells, P.; Abouarghoub, W.; Pettit, S.; Beresford, A. A socio-technical transitions perspective for assessing future sustainability following the COVID-19 pandemic. Sustain. Sci. Pract. Policy 2020, 16, 29-36. [CrossRef]

19. Bodenheimer, M.; Leidenberger, J. COVID-19 as a window of opportunity for sustainability transitions? Narratives and communication strategies beyond the pandemic. Sustain. Sci. Pract. Policy 2020, 16, 61-66. [CrossRef]

20. Bates, A.E.; Primack, R.B.; Moraga, P.; Duarte, C.M. COVID-19 pandemic and associated lockdown as a "Global Human Confinement Experiment" to investigate biodiversity conservation. Biol. Conserv. 2020, 248, 108665. [CrossRef] [PubMed]

21. Le, T.; Wang, Y.; Liu, L.; Yang, J.; Yung, Y.L.; Li, G.; Seinfeld, J.H. Unexpected air pollution with marked emission reductions during the COVID-19 outbreak in China. Science 2020, 369, 702-706. [CrossRef]

22. Corlett, R.T.; Primack, R.B.; Devictor, V.; Maas, B.; Goswami, V.R.; Bates, A.E.; Koh, L.P.; Regan, T.J.; Loyola, R.; Pakeman, R.J. Impacts of the coronavirus pandemic on biodiversity conservation. Biol. Conserv. 2020, 246, 108571. [CrossRef]

23. Searle, A.; Turnbull, J. Resurgent natures? More-than-human perspectives on COVID-19. Dialogues Hum. Geogr. 2020, 10, $291-295$. [CrossRef]

24. McCleery, R.A.; Fletcher, R.J;; Kruger, L.M.; Govender, D.; Ferreira, S.M. Conservation needs a COVID-19 bailout. Science 2020, 369, 515-516.

25. Zambrano-Monserrate, M.A.; Ruano, M.A.; Sanchez-Alcalde, L. Indirect effects of COVID-19 on the environment. Sci. Total Environ. 2020, 728, 138813. [CrossRef]

26. United Nations. Sustainable Development Goals Report 2020. Available online: https://unstats.un.org/sdgs/report/2020/\#sdggoals (accessed on 15 October 2020). 
27. Naidoo, R.; Fisher, B. Reset Sustainable Development Goals for a Pandemic World; Nature: New York, NY, USA, 2020; Volume 583, pp. 198-201.

28. Daniels, M.J.; Cohen, M.G.; Bavry, A.A.; Kumbhani, D.J. Reperfusion of STEMI in the COVID-19 Era-Business as Usual? Circulation 2020, 141, 1948-1950. [CrossRef]

29. de Caro, F.; Hirschmann, T.M.; Verdonk, P. Returning to orthopaedic business as usual after COVID-19: Strategies and options. Knee Surg. Sports Traumatol. Arthrosc. 2020, 28, 1699-1704. [CrossRef] [PubMed]

30. Oldekop, J.A.; Horner, R.; Hulme, D.; Adhikari, R.; Agarwal, B.; Alford, M.; Bakewell, O.; Banks, N.; Barrientos, S.; Bastia, T. COVID-19 and the case for global development. World Dev. 2020, 134, 105044. [CrossRef] [PubMed]

31. Lambert, H.; Gupte, J.; Fletcher, H.; Hammond, L.; Lowe, N.; Pelling, M.; Raina, N.; Shahid, T.; Shanks, K. COVID-19 as a global challenge: Towards an inclusive and sustainable future. Lancet Planet. Health 2020, 4, e312-e314. [CrossRef]

32. Goffman, E. In the wake of COVID-19, is glocalization our sustainability future? Sustain. Sci. Pract. Policy 2020, 16, 48-52. [CrossRef]

33. Svampa, M. Reflexiones Para un Mundo Post-Coronavirus I Nueva Sociedad. Available online: https://nuso.org/articulo/ reflexiones-para-un-mundo-post-coronavirus / (accessed on 15 September 2020).

34. Henry, M.S.; Bazilian, M.D.; Markuson, C. Just transitions: Histories and futures in a post-COVID world. Energy Res. Soc. Sci. 2020, 68, 101668. [CrossRef]

35. Kołodko, G.W. After the Calamity: Economics and Politics in the Post-Pandemic World. Pol. Sociol. Rev. 2020, 210, 137-156.

36. Leach, M.; MacGregor, H.; Scoones, I.; Wilkinson, A. Post-pandemic transformations: How and why COVID-19 requires us to rethink development. World Dev. 2020, 138, 105233. [CrossRef]

37. Perspectives on the Economics of the Environment in the Shadow of Coronavirus. Environ. Resour. Econ. 2020, 76, 447-517. [CrossRef]

38. Brand, U. Green economy and green capitalism: Some theoretical considerations. J. Für Entwickl. 2012, 28, 118-137. [CrossRef]

39. Bennett, N.J.; Cisneros-Montemayor, A.M.; Blythe, J.; Silver, J.J.; Singh, G.; Andrews, N.; Calò, A.; Christie, P.; Di Franco, A.; Finkbeiner, E.M. Towards a sustainable and equitable blue economy. Nat. Sustain. 2019, 2, 991-993. [CrossRef]

40. Kuzemko, C.; Bradshaw, M.; Bridge, G.; Goldthau, A.; Jewell, J.; Overland, I.; Scholten, D.; Van de Graaf, T.; Westphal, K. COVID-19 and the politics of sustainable energy transitions. Energy Res. Soc. Sci. 2020, 68, 101685. [CrossRef] [PubMed]

41. Mukanjari, S.; Sterner, T. Charting a "green path" for recovery from COVID-19. Environ. Resour. Econ. 2020, 76, 825-853. [CrossRef] [PubMed]

42. Ahmed, F.; Ahmed, N.; Pissarides, C.; Stiglitz, J. Why inequality could spread COVID-19. Lancet Public Health 2020, 5, e240. [CrossRef]

43. Hevia, C.; Neumeyer, A. Un Marco Conceptual Para Analizar el Impacto Económico del COVID-19 y Sus Repercusiones en Las Politicas; PNUD LAC C19 PDS; PNUD América Latina y el Caribe: New York, NY, USA, 2020.

44. CEPAL, N. Enfrentar Los Efectos Cada Vez Mayores Del COVID-19 Para Una Reactivación Con Igualdad: Nuevas Proyecciones; CEPAL: Santiago, Chile, 2020.

45. CEPAL-OIT Coyuntura Laboral en América Latina y el Caribe. El trabajo en tiempos de pandemia: Desafíos frente a la enfermedad por coronavirus (COVID-19). Coyunt. Labor. En América Lat. El Caribe 2020, 22, 1-60.

46. León, D.C.; Cárdenas, J.C. Lecciones del COVID-19 Para Una Agenda de Sostenibilidad en América Latina E Caribe; PNUD LAC C19 PDS; PNUD América Latina y el Caribe: New York, NY, USA, 2020; Volume 1, pp. 1-35.

47. Open Democracy. As the Pandemic Continues to Accelerate, so does the Deforestation of the Amazon. Available online: https: / / www.opendemocracy.net/en/democraciaabierta/se-acelera-la-pandemia-y-se-acelera-la-deforestacion-del-amazonas-en / (accessed on 14 September 2020).

48. Amazon Fires: Year-on-Year Numbers Doubled in October. BBC News. Available online: https://www.bbc.com/news/worldlatin-america-54779877 (accessed on 4 November 2020).

49. FCDS Conservación y Desarrollo Fundación para la Conservación y el Desarrollo Sostenible. FCDS Conserv. Desarro. 2020, 1, 1-7.

50. Himitian, E.; Arambillet, D. El país en Llamas: Se Queman 175.000 Hectáreas de Bosques y Humedales-LA NACION. Available online: https:/ / www.lanacion.com.ar/sociedad/el-pais-llamas-se-quema-area-bosques-nid2432281/amp?_twitter_ impression $=$ true\&s $=03$ (accessed on 15 September 2020).

51. ODS. Índice ODS 2019 para América Latina y el Caribe; Centro de los Objetivos de Desarrollo Sostenible para América Latina y el Caribe: Bogota, Colombia, 2020.

52. ODS. Impactos del COVID-19 en los Objetivos de Desarrollo Sostenible; Centro de los Objetivos de Desarrollo Sostenible para América Latina y el Caribe: Bogota, Colombia, 2020.

53. López-Feldman, A.; Chávez, C.; Vélez, M.A.; Bejarano, H.; Chimeli, A.B.; Féres, J.; Robalino, J.; Salcedo, R.; Viteri, C. Environmental impacts and policy responses to COVID-19: A view from Latin America. Environ. Resour. Econ. 2020, 1-6. [CrossRef]

54. Leff, E. La geopolítica de la biodiversidad y el desarrollo sustentable. Rev. Obs. Soc. América Lat. 2005, 17, 185-209.

55. Gudynas, E. Buen Vivir: Germinando alternativas al desarrollo. América Lat. En Mov. 2011, 462, 1-20.

56. Galafassi, G. Renovadas versiones de un proceso histórico en marcha. La predación del territorio y la naturaleza como acumulación. Rev. Theomai 2012, 25, 1-14.

57. Zarrilli, A.G. Ambiente, producción y mercado. El impacto transformador en una economía periférica, el Gran Chaco Argentino en el siglo XX. Areas Rev. Int. Cienc. Soc. 2016, 121-139. 
58. Morea, J.P. Modelos de desarrollo y soberanía en América Latina: Una visión desde la gestión territorial. Geopolítica S 2020, 11, 71-93. [CrossRef]

59. Gligo, N.; Alonso, G.; Barkin, D.; Brailovsky, A.; Brzovic, F.; Carrizosa, J.; Durán, H.; Fernández, P.; Gallopín, G.C.; Leal, J. La tragedia ambiental de América Latina y el Caribe; Naciones Unidas Comisión Económica para América Latina y el Caribe (CEPAL): Santiago, Chile, 2020; 127p.

60. Gudynas, E. Diez tesis urgentes sobre el nuevo extractivismo. Extr. Política Soc. 2009, 187.

61. Svampa, M. Consenso de los commodities, giro ecoterritorial y pensamiento crítico en América Latina. Osal 2012, 13, 15-38.

62. Brand, U.; Dietz, K.; Lang, M. Neo-Extractivism in Latin America-one side of a new phase of global capitalist dynamics. Cienc. Política 2016, 11, 125-159. [CrossRef]

63. Azamar, A.; Ponce, J.I. Extractivismo y desarrollo: Los recursos minerales en México. Probl. Desarro. 2014, 45, 137-158.

64. Delgado, J.O. Sociedades posneoliberales en América Latina y persistencia del extractivismo. Econ. Inf. 2016, 396, 84-95. [CrossRef]

65. Merchand Rojas, M.A. Neoextractivismo y conflictos ambientales en América Latina. Espiral Guadalaj. 2016, $23,155-192$. [CrossRef]

66. Landa, Y. Renta extractiva y la minería del cobre en el Perú. Probl. Desarro. 2017, 48, 141-168. [CrossRef]

67. Svampa, M. Continuidad y radicalización del neoextractivismo en Argentina. Rev. Perf. Económ. 2018, 3, 87-97. [CrossRef]

68. Bosoer, F.; Turzi, M. La pandemia del 2020 en el debate teórico de las Relaciones Internacionales. Geopolitica 2020, 11, 153-163. [CrossRef]

69. Leff, E. Political ecology: A Latin American perspective. Desenvolv. E Meio Ambiente 2012, 35, 29-64. [CrossRef]

70. Bull, B.; Aguilar-Stoen, M.C. Environmental Politics in Latin America: Elite Dynamics, the Left Tide and Sustainable Development; Routledge: New York, NY, USA, 2014; ISBN 1-317-65379-3.

71. Bebbington, A. Political ecologies of resource extraction: Agendas pendientes. Eur. Rev. Lat. Am. Caribb. Stud. Eur. Estud. Latinoam. Caribe 2015, 100, 85-98. [CrossRef]

72. De Castro, F.; Hogenboom, B.; Baud, M. Environmental Governance in Latin America; Springer Nature: Berlin/Heidelberg, Germany, 2016; ISBN 1-137-50572-9.

73. Mesquida, F. El Gobierno Atrasa La Firma Del Acuerdo Porcino Con China Por el Tema Ambiental. Available online: https: //www.infocampo.com.ar/el-gobierno-atrasa-la-firma-del-acuerdo-porcino-con-china-por-el-tema-ambiental/ (accessed on 15 September 2020).

74. Horner, R. Towards a new paradigm of global development? Beyond the limits of international development. Prog. Hum. Geogr. 2020, 44, 415-436. [CrossRef]

75. Represión y Muertos en Perú: El Gobierno de Merino Pende de un Hilo. Available online: http:/ /www.laizquierdadiario.com/ Represion-y-muertos-en-Peru-el-Gobierno-de-Merino-pende-de-un-hilo (accessed on 19 November 2020).

76. Crisis en Perú. Asumió Francisco Sagasti, el Tercer Presidente en Una Semana. Available online: https:/ / www.lanacion.com.ar/ el-mundo/francisco-sagasti-asumio-peru-tercer-presidente-semana-nid2512690 (accessed on 19 November 2020).

77. World Bank Group to Launch New Multi-donor Trust Fund to Help Countries Prepare for Disease Outbreaks. Available online: https:/ /www.worldbank.org/en/news/statement/2020/04/15/world-bank-group-to-launch-new-multi-donor-trustfund-to-help-countries-prepare-for-disease-outbreaks (accessed on 3 December 2020).

78. \$2.5 Trillion COVID-19 Rescue Package Needed for World's Emerging Economies. Available online: https://news.un.org/en/ story/2020/03/1060612 (accessed on 3 December 2020).

79. Según el PNUD, un Ingreso Básico Temporal Para Proteger a Las Personas Más Pobres Del Mundo Podría Desacelerar el Aumento de Los Casos de COVID-19 I PNUD. Available online: https://www.undp.org/content/undp/es/home/news-centre/news/20 20/Temporary_Basic_Income_to_protect_the_worlds_poorest_people_slow_COVID19.html (accessed on 3 December 2020).

80. Payne, A. Germany is Beginning a Universal-Basic-Income Trial with People Getting \$1,400 a Month for 3 Years. Available online: https: / / www.businessinsider.com/germany-begins-universal-basic-income-trial-three-years-2020-8 (accessed on 3 December 2020).

81. Finn, B.M.; Kobayashi, L.C. Structural inequality in the time of COVID-19: Urbanization, segregation, and pandemic control in sub-Saharan Africa. Dialogues Hum. Geogr. 2020, 10, 217-220. [CrossRef]

82. Warjri, L.; Shah, A. India and Africa: Charting a Post-COVID-19 Future. Observer Research Foundation. 2020. Available online: https:/ / www.orfonline.org/research/india-and-africa-charting-a-postCOVID-19-future-68453 (accessed on 20 November 2020).

83. Barreñada Bajo, I. Pandemia: Anexiones territoriales en Israel y comorbilidad en Palestina. Geopolit. Rev. Estud. Sobre Espac. Y Poder 2020, 11, 93-104. [CrossRef] 